\title{
An Analysis of the Growth of Indian Insurance Industry with Reference to Top Ten Economies of the World
}

\author{
Parkash Chandel ${ }^{1}$ \& Naveen $\mathrm{Kumar}^{2, *}$ \\ ${ }^{1}$ Deptt. of Commerce, Himachal Pradesh University (CES), Shimla (H.P.), India \\ ${ }^{2}$ Deptt. of Commerce, Vallabh Govt. College, Mnadi, (H.P.), India \\ *Correspondence: Deptt. of Commerce, Vallabh Govt. College, Mnadi, (H.P.), India. E-mail: \\ naveenkumarsaini09@gmail.com
}

Received: June 12, 2016

doi:10.5430/sass.v3n2p36
Accepted: July 10, 2016 Online Published: July 25, 2016

URL: http://dx.doi.org/10.5430/sass.v3n2p36

\begin{abstract}
With the insurance sector in full bloom, today, it would not be wrong to say that in the present market scenario, there is an insurance available for just about anything and everything. Insurance is no doubt an area of immense importance with regard to the financial and monetary sectors of every individual. The whole idea behind insurance is, it is a security tool which is designed to secure the financial status of an individual and also of his/her dependents, in case he/she undergoes an unforeseen loss related to health, property or liability. Insurance sector in India has been growing continuously after its opening up for private players in 1999. Therefore an attempt has been made in this paper to study the growth of Indian insurance sector with reference to the growth of insurance sector in top ten economies of the world. To study the growth and opportunities in the insurance sector, premium income, growth in premium income, insurance density and insurance penetration have been measured. The measure of insurance penetration and density reflects the level of development of insurance sector in a country. While insurance penetration is measured as the percentage of insurance premium to GDP, insurance density is calculated as the ratio of premium to population.
\end{abstract}

Keywords: insurance; growth; economies; insurance density; insurance penetration; premium; risk

\section{Introduction}

It is a commonly acknowledged phenomenon that there are countless risks in every sphere of life, for property there are fire risk; for shipment of goods, there are perils of sea; for human life, there are risks of death or disability. The chances of occurrences of the events causing losses are quite uncertain because they may or may not take place. The risk is the result of effect of any unforeseen event or its happening. The future is unpredictable and full of uncertainties. Risks are inherent in all forms of economical, political, social, environmental and business activities. Planning alone cannot solve or protect against uncertainties. Therefore, Insurance has emerged and developed as a means to protect and provide coverage against risks and uncertainties. Insurance is a contract which provides financial risk coverage to the insured against any adverse event for a payment called premium.

The insurance industry in India has seen an array of changes in the past two decades. The economic scenario which emerged after globalization, privatization and liberalization has thrown new challenges before insurance sector. Now it has to be more competitive in order to meet the needs and demands of its customers. Indian insurance has been growing continuously after its opening up for private sector in 1999 but it still in its infancy stage if comparison is made other top economy of the world. There an attempt has been made in this paper to study the growth of Indian insurance industry in comparison to other top economies of the world.

\section{Review of Literature}

Verma (2000), in her thesis, evaluated the performance of the GIC and its subsidiary companies over the years, throwing light on the profitable effects of the various insurance sector reforms on the future development of General 
Insurance in the country. The study found that the GIC along with its subsidiaries has emerged not only as a strong insurance institution but also as influential institutional investors in the financial market of India due to large amount of funds at its disposal. The study suggested that GIC should bring reform in pricing the General Insurance contracts and use information technology for better management, customer service, efficiency and competitiveness.

Rudolf (2001), in his paper examined the key factors and latest trends determining profitability in the major non-life insurance markets. The study focused on the non-life insurance markets of the group of seven countries (G7) mainly for the period 1996 to 2000 . The study found that underwriting results and investment yields are negatively correlated. The research suggested that due to uncertain prospects for investment results, the insurers must focus on underwriting results to achieve greater profitability.

Lai and Limpaphayom (2003), in their study examined the relation between organizational structure and firm performance in the Japanese non-life insurance industry. The results indicated that the stock companies that belong to one of the six horizontal Keiretsu groups have lower expense and lower levels of free cash flow than independent stock and mutual insurance companies. Keiretsu insurers also have higher profitability and higher loss ratios than independent insurers. There was also evidence that mutual insurers have higher levels of free cash flows, higher investment incomes and lower financial leverage than their stock counterparts. Overall, empirical evidence suggested that each structure has its own comparative advantage.

Banerjee (2004), in his article, "Insurance Regulation in India and Future Directions," concluded that the insurance industry will face greater competition from other financial service providers along all aspects of their value chain. Insurers for instance, with their significant and growing asset base, shall have to develop asset management capabilities and expertise on par with professional fund managers, otherwise they will face pressure to farm out their funds for professional management.

Festus (2011), in his study, "Achieving Competitive Advantage in Insurance Industry: The Impact of Marketing Innovation and Creativity", concluded that creativity and innovation in providing new and innovative services is an important factor in order to satisfy the clients need and that creativity and innovation in pricing and promotion and innovation and creativity in distribution, technological innovation are crucial in attracting new clients.

\section{Objectives of the Study}

- To study the growth of Indian insurance industry after its opening up for private players.

- To study the growth of Indian insurance industry with reference to top economies of the world.

\section{Research Methodology}

To study the growth and opportunities in the insurance sector of any country, premium income, growth in premium income, insurance density and insurance penetration should be measured. To study the Indian insurance industry in world perspective, we have compared the premium income, insurance density and insurance penetration of select countries of the world. We have compared the insurance industries of the top ten economies of the world based on the size of their Gross Domestic Product (GDP). The measure of insurance penetration and density reflects the level of development of insurance sector in a country. While insurance penetration is measured as the percentage of insurance premium to GDP, insurance density is calculated as the ratio of premium to population (per capita premium).

\subsection{Top Ten Economies of the World}

Top ten economies of the world based on the size of their GDP have been shown in Table 1. 
Table 1. Top Ten Economies of the World

\begin{tabular}{lc}
\hline COUNTRY & GDP (in trillions of US Dollars) \\
\hline United States & 15.5 \\
China & 8.3 \\
Japan & 6 \\
Germany & 3.4 \\
France & 2.6 \\
United Kingdom & 2.4 \\
Brazil & 2.4 \\
Italy & 2 \\
Russia & 2 \\
India & 1.9 \\
\hline
\end{tabular}

Source: IMF World Economic Outlook 2012

Table 1.1 reveals that out of ten economies of the world United States has the highest Gross Domestic Product, that is, $\$ 15.5$ trillion, followed by China ( $\$ 8.3$ trillion) and Japan ( $\$ 6$ trillion). India is at tenth position with $\$ 1.9$ trillion GDP.

\subsection{Life Insurance Volume}

Country wise life insurance volume has been shown in Table 2.

Table 2. Life Insurance Volume in USD (in millions of USD)

\begin{tabular}{|c|c|c|c|c|c|c|c|c|c|c|c|c|c|}
\hline COUNTRY & 2001 & 2002 & 2003 & 2004 & 2005 & 2006 & 2007 & 2008 & 2009 & 2010 & 2011 & 2012 & 2013 \\
\hline U.S. & 443413 & 480452 & 480919 & 494818 & 517074 & 533649 & 578357 & 578211 & 492345 & 506228 & 537570 & 567756 & 532858 \\
\hline CHINA & 15556 & 25054 & 32442 & 35407 & 39592 & 45092 & 58677 & 95831 & 109175 & 142999 & 134539 & 141208 & 152121 \\
\hline JAPAN & 356731 & 354553 & 381335 & 386839 & 375958 & 362766 & 330651 & 367112 & 399100 & 440950 & 524668 & 524372 & 422733 \\
\hline GERMANY & 55631 & 60860 & 76738 & 84535 & 90225 & 94911 & 102419 & 111278 & 111775 & 114868 & 113869 & 106411 & 114349 \\
\hline FRANCE & 75146 & 80411 & 105436 & 128813 & 154058 & 177902 & 186993 & 181146 & 194077 & 192428 & 174753 & 149346 & 160156 \\
\hline U.K. & 152717 & 159656 & 154842 & 189591 & 199612 & 311691 & 349740 & 342759 & 217681 & 213831 & 210067 & 205918 & 222893 \\
\hline BRAZIL & 4511 & 4749 & 6306 & 8199 & 10556 & 13699 & 18285 & 22419 & 24781 & 33246 & 41046 & 44784 & 49417 \\
\hline ITLAY & 41481 & 52444 & 71694 & 82083 & 91740 & 89576 & 88215 & 82623 & 115290 & 122063 & 105089 & 93273 & 117978 \\
\hline RUSSIA & 4783 & 3313 & 4868 & 3544 & 904 & 571 & 873 & 765 & 636 & 901 & 1185 & 1732 & 2666 \\
\hline INDIA & 10504 & 12274 & 13590 & 16919 & 20175 & 37220 & 47132 & 48860 & 57114 & 67810 & 60442 & 53300 & 52174 \\
\hline
\end{tabular}

SOURCE: SWISS RE, SIGMA NO.6/2002 TO NO.3/2014

It is evident from the table that USA top in the life insurance volume followed by Japan and Germany. Russia is at the lowest level. There is an increasing trend in the life insurance volume in all the countries except few years. In India, It has increased almost six times from 10504 million dollars in 2001 to 67810 million dollars in 2011. It has increased continuously after opening up of the insurance sector in 2000 up to the year 2011, there after it has shown a decreasing trend for next three years. The figures of life insurance volume are impressive if a comparison is made with other fast developing countries like Brazil and Russia but India lagging behind the figures of China. If the comparison is made with the developed nations like United States, United Kingdom, Japan, Germany, France, Italy, India is far behind from these countries. The worldwide life insurance volume has also been increasing continuously. In the Indian context, no doubt, life insurance volume has increased during the period under study but it is still very low as compared to the developed nations.

\subsection{Non-Life Insurance Volume}

Country wise no-life insurance volume has been shown in Table 3. 
Table 3. Non Life Insurance Volume in USD (in millions of USD)

\begin{tabular}{llllllllllllll}
\hline COUNTRY & $\mathbf{2 0 0 1}$ & $\mathbf{2 0 0 2}$ & $\mathbf{2 0 0 3}$ & $\mathbf{2 0 0 4}$ & $\mathbf{2 0 0 5}$ & $\mathbf{2 0 0 6}$ & $\mathbf{2 0 0 7}$ & $\mathbf{2 0 0 8}$ & $\mathbf{2 0 0 9}$ & $\mathbf{2 0 1 0}$ & $\mathbf{2 0 1 1}$ & $\mathbf{2 0 1 2}$ & $\mathbf{2 0 1 3}$ \\
\hline U.S. & 460608 & 519858 & 574579 & 603018 & 625838 & 636452 & 651311 & 662432 & 647401 & 659915 & 667107 & 703128 & 726397 \\
CHINA & 9928 & 11834 & 14468 & 16765 & 20539 & 25713 & 33810 & 44987 & 53872 & 71628 & 87319 & 104302 & 125844 \\
JAPAN & 89114 & 91028 & 97530 & 105587 & 100523 & 97495 & 94182 & 106085 & 106856 & 116489 & 130741 & 129740 & 108773 \\
GERMANY & 68051 & 74911 & 94073 & 106261 & 107026 & 109633 & 120407 & 131807 & 126591 & 124949 & 131292 & 125497 & 132813 \\
FRANCE & 38449 & 44649 & 58244 & 65811 & 68162 & 73262 & 81907 & 91861 & 88993 & 87654 & 98359 & 93112 & 94598 \\
U.K. & 65664 & 77026 & 91891 & 105241 & 105126 & 106676 & 113946 & 107393 & 91560 & 96191 & 109486 & 105500 & 106750 \\
BRAZIL & 8953 & 7852 & 8259 & 9843 & 13399 & 16691 & 20501 & 25074 & 23979 & 30847 & 27240 & 37483 & 39513 \\
ITLAY & 27506 & 31616 & 40066 & 46728 & 47453 & 49103 & 54112 & 58066 & 54070 & 52285 & 55426 & 50945 & 50576 \\
RUSSIA & 4687 & 6266 & 9220 & 12809 & 16618 & 20932 & 28973 & 38013 & 38940 & 40742 & 42071 & 24296 & 25755 \\
INDIA & 2459 & 3197 & 3712 & 4330 & 4848 & 5812 & 7243 & 7329 & 7970 & 10562 & 12187 & 13142 & 13401 \\
WORLD & 969074 & 1090775 & 1268157 & 1395218 & 1452011 & 1514094 & 1667780 & 1779316 & 1738529 & 1818893 & 1968179 & 1991650 & 2032850 \\
\hline
\end{tabular}

Source: SWISS RE, SIGMA NO.6/2002 TO NO.3/2014

It is evident from the table that non-life insurance volume has increased continuously in all the countries under study during study period. Again USA is at the top in non-life insurance volume throughout the study period. India is at the lowest level in non-life insurance volume. In India non-life insurance volume has also increased continuously. It has increased from 2459 million dollars in 2001 to 13401 million dollars in 2013 which looks impressive, but if the comparison is made with other top economies of the world under study, India has the lowest non-life insurance volume. Non-life insurance volume has also increased worldwide from 969074 million dollars to 2082850 million dollars in 2013.

\subsection{Life Insurance Density}

Country wise life insurance density has been depicted in Table 4 .

Table 4. Life Insurance Density (USD)

\begin{tabular}{llllllllllllll}
\hline COUNTRY & $\mathbf{2 0 0 1}$ & $\mathbf{2 0 0 2}$ & $\mathbf{2 0 0 3}$ & $\mathbf{2 0 0 4}$ & $\mathbf{2 0 0 5}$ & $\mathbf{2 0 0 6}$ & $\mathbf{2 0 0 7}$ & $\mathbf{2 0 0 8}$ & $\mathbf{2 0 0 9}$ & $\mathbf{2 0 1 0}$ & $\mathbf{2 0 1 1}$ & $\mathbf{2 0 1 2}$ & $\mathbf{2 0 1 3}$ \\
\hline U.S. & 1602 & 1662.6 & 1657.5 & 1692.5 & 1753.2 & 1789.5 & 1922 & 1900.6 & 1602.6 & 1631.8 & 1716 & 1808 & 1684 \\
CHINA & 12.2 & 19.5 & 25.1 & 27.3 & 30.5 & 34.1 & 44.2 & 71.7 & 81.1 & 105.5 & 99 & 103 & 110 \\
JAPAN & 2806.4 & 2783.9 & 3002.9 & 3044 & 2956.3 & 2829.3 & 2883.9 & 2869.5 & 3138.7 & 3472.8 & 4138 & 4143 & 3346 \\
GERMANY & 674.3 & 736.7 & 930.4 & 1021.3 & 1042.1 & 1136.1 & 1234.1 & 1346.5 & 1359.7 & 1402.2 & 1389 & 1299 & 1392 \\
FRANCE & 1268.2 & 1349.5 & 1767.9 & 2150.2 & 2474.6 & 2922.5 & 2928.3 & 2791.9 & 2979.8 & 2937.5 & 2638 & 2239 & 2391 \\
U.K. & 2567.9 & 2679.4 & 2617.1 & 3190.4 & 3287.1 & 5139.6 & 5730.5 & 5582.1 & 3527.6 & 3436.3 & 3347 & 3256 & 3474 \\
BRAZIL & 10.8 & 27.2 & 35.8 & 45.9 & 56.8 & 72.5 & 95.3 & 115.4 & 127.9 & 169.9 & 208 & 226 & 246 \\
ITLAY & 720.8 & 904.9 & 1238.3 & 1417.2 & 1449.8 & 1492.8 & 1439.4 & 1342.4 & 1878.3 & 1978.7 & 1696 & 1473 & 1895 \\
RUSSIA & 33.2 & 23.1 & 33.9 & 24.8 & 6.3 & 4 & 6.1 & 5.4 & 4.5 & 6.4 & 8 & 12.1 & 19 \\
INDIA & 9.1 & 11.7 & 12.7 & 15.7 & 18.7 & 33.2 & 40.4 & 41.2 & 47.7 & 55.7 & 49 & 42.7 & 41 \\
WORLD & 235 & 247.3 & 267.1 & 291.5 & 299.5 & 330.6 & 358.1 & 369.7 & 341.2 & 364.3 & 378 & 372.6 & 366 \\
\hline
\end{tabular}

Source: SWISS RE, SIGMA NO.6/2002 TO NO.3/2014

Table explains the life insurance density in India as well as at the global level. Life insurance density is calculated as a ratio (in percentage terms) of premium to total population. It is clear from the table that Japan is at the top in Life insurance density followed by UK and France. It is also evident from the table that life insurance density in India has continuously increased from the year 2001 to 2011; thereafter it decreased during next three years. It has increased from $\$ 9.1$ in 2001 to its highest level $\$ 55.7$ in 2010. World -wide the life insurance density has also shown an increasing trend and it increased from $\$ 235$ to $\$ 378$ in 2011 thereafter it decreased during next two year. As is evident from the table, despite an impressive growth in life insurance density in the post reform period in India, it is still very small as compare to other top economies of the world under study. India has the lowest life insurance density except Russia as compare to other countries of the world under study. 


\subsection{Non-Life Insurance Density}

Country wise non-life insurance density has been depicted in Table 5.

Table 5. Non-Life Insurance Density (USD)

\begin{tabular}{|c|c|c|c|c|c|c|c|c|c|c|c|c|c|}
\hline COUNTRY & 2001 & 2002 & 2003 & 2004 & 2005 & 2006 & 2007 & 2008 & 2009 & 2010 & 2011 & 2012 & 2013 \\
\hline U.S. & 1664.1 & 1799 & 1980.2 & 2062.6 & 2122 & 2134.2 & 2164.4 & 2177.4 & 2107.3 & 2127.2 & 2130 & 2239 & 2296 \\
\hline CHINA & 7.8 & 9.2 & 11.2 & 12.9 & 15.8 & 19.4 & 25.5 & 33.7 & 40 & 52.9 & 64 & 76 & 91 \\
\hline JAPAN & 701.1 & 714.7 & 768 & 830.8 & 790.4 & 760.4 & 736 & 829.2 & 840.4 & 917.4 & 1031 & 1025 & 861 \\
\hline GERMANY & 809.9 & 891.1 & 1120.8 & 1265.3 & 1268.4 & 1300.7 & 1427.9 & 1572.7 & 1518.7 & 1501.6 & 1578 & 1505 & 1585 \\
\hline FRANCE & 630.6 & 714.5 & 930.5 & 1057.7 & 1093.9 & 1152.9 & 1219.3 & 1339.2 & 1289.4 & 1249 & 1403 & 1304 & 1345 \\
\hline U.K. & 825.9 & 1199.7 & 1441.4 & 1318 & 1311.9 & 1327.1 & 1383.2 & 1275.7 & 1051.2 & 1060.2 & 1188 & 1094 & 1087 \\
\hline BRAZIL & 53.2 & 45 & 46.8 & 55.2 & 72.1 & 88.4 & 106.9 & 129.1 & 123.8 & 157.7 & 189 & 189 & 197 \\
\hline ITLAY & 465.5 & 530.5 & 674.8 & 800.7 & 814.1 & 809.5 & 882.7 & 921.3 & 850.8 & 787.3 & 834 & 748 & 750 \\
\hline RUSSIA & 32.6 & 43.5 & 64.3 & 89.6 & 116.5 & 146 & 203.3 & 268.1 & 276.4 & 290.4 & 295 & 170 & 180 \\
\hline INDIA & 2.4 & 3 & 3.5 & 4 & 4.4 & 5.2 & 6.2 & 6.2 & 6.7 & 8.7 & 10 & 11 & 11 \\
\hline WORLD & 158.2 & 175.6 & 202.5 & 220 & 219 & 224.2 & 249.6 & 264.2 & 253.9 & 263 & 283 & 283 & 285 \\
\hline
\end{tabular}

Source: SWISS RE, SIGMA NO.6/2002 TO NO.3/2014

The table exhibits the non-life insurance density in India as well at the global level. The non-life insurance density is measured as a ratio of premium to total population. It is evident from the table that USA is at the top in non-life density followed by Germany. India is at the bottom in non-life insurance density. It is clear from the table that non-life insurance density in India has increased about five times during the period under study. It has increased from \$2.4 in 2001 to \$11 in 2013. Even the developing countries like China, Brazil and Russia registered an impressive growth in the non-life insurance density. World- wide, the non-life insurance density has also shown an increasing trend, and it has increased from $\$ 158.2$ to $\$ 285$. It is evident from the table that non-life insurance density in India is lowest as compare to the other countries of the world under study. It seems that even the reform process has failed to provide the desired results despite the fact that the Indian insurance sector is still unexplored and untapped.

\subsection{Life Insurance Penetration}

Country wise life insurance penetration has been depicted in Table 6.

Table 6. Life Insurance Penetration (premium in percentage of GDP)

\begin{tabular}{lccccccccccccc}
\hline COUNTRY & $\mathbf{2 0 0 1}$ & $\mathbf{2 0 0 2}$ & $\mathbf{2 0 0 3}$ & $\mathbf{2 0 0 4}$ & $\mathbf{2 0 0 5}$ & $\mathbf{2 0 0 6}$ & $\mathbf{2 0 0 7}$ & $\mathbf{2 0 0 8}$ & $\mathbf{2 0 0 9}$ & $\mathbf{2 0 1 0}$ & $\mathbf{2 0 1 1}$ & $\mathbf{2 0 1 2}$ & $\mathbf{2 0 1 3}$ \\
\hline U.S. & 4.4 & 4.6 & 4.38 & 4.22 & 4.14 & 4 & 4.2 & 4.1 & 3.5 & 3.5 & 3.6 & 3.65 & 3.2 \\
CHINA & 1.34 & 2.03 & 2.3 & 2.21 & 1.78 & 1.7 & 1.8 & 2.2 & 2.3 & 2.5 & 1.8 & 1.70 & 1.6 \\
JAPAN & 8.85 & 8.64 & 8.61 & 8.26 & 8.32 & 8.3 & 7.5 & 7.6 & 7.8 & 8 & 8.8 & 9.17 & 8.8 \\
GERMANY & 3 & 3.06 & 3.17 & 3.11 & 3.06 & 3.1 & 3.1 & 3 & 3.3 & 3.5 & 3.2 & 3.12 & 3.1 \\
FRANCE & 5.75 & 5.61 & 5.99 & 6.38 & 7.08 & 7.9 & 7.3 & 6.2 & 7.2 & 7.4 & 6.2 & 5.64 & 5.7 \\
U.K. & 10.73 & 10.19 & 8.62 & 8.92 & 8.9 & 13.1 & 12.6 & 12.8 & 10 & 9.5 & 8.7 & 8.44 & 8.8 \\
BRAZIL & 0.36 & 1.05 & 1.28 & 1.36 & 1.33 & 1.3 & 1.4 & 1.4 & 1.6 & 1.6 & 1.7 & 1.99 & 2.2 \\
ITLAY & 3.81 & 4.39 & 4.82 & 4.86 & 4.86 & 4.7 & 2.6 & 3.5 & 5.3 & 5.8 & 4.7 & 4.46 & 5.5 \\
RUSSIA & 1.55 & 0.96 & 1.12 & 0.61 & 0.12 & 0.1 & 0.1 & 0 & 0 & 0 & 0.1 & 0.09 & 0.1 \\
INDIA & 2.15 & 2.59 & 2.26 & 2.53 & 2.53 & 4.1 & 4 & 4 & 4.6 & 4.4 & 3.4 & 3.17 & 3.1 \\
WORLD & 4.68 & 4.76 & 4.59 & 4.55 & 4.34 & 4.5 & 4.4 & 4.1 & 4 & 4 & 3.8 & 3.69 & 3.5 \\
\hline
\end{tabular}

Source: SWISS RE, SIGMA NO.6/2002 TO NO.3/2014

Table explains the life insurance penetration in the global perspective. Life insurance penetration is measured as a ratio (in percentage terms) of the insurance premium to the Gross Domestic Product (GDP). It is clear from the table the life insurance penetration in India has increased from $2.15 \%$ in 2001 to $4.6 \%$ in 2009 , thereafter it decreased during next four ant reached to $3.1 \%$ in 2013 . The worldwide penetration of life insurance is almost stagnant. U.K. and Japan has topped in the life insurance penetration. The figures of India look better if the comparison is made with other developing countries like China, Brazil and Russia. The figures of Germany and Italy look slightly better 
than the figures of India. However, India is far behind the developed nations like USA, U.K, Japan and France as far as the question of life insurance penetration is concerned.

\subsection{Non-Life Insurance Penetration}

Country wise non-life insurance penetration has been depicted in Table 7.

Table 7. Non-Life Insurance Penetration (Premium in Percentage of GDP)

\begin{tabular}{|c|c|c|c|c|c|c|c|c|c|c|c|c|c|}
\hline COUNTRY & 2001 & 2002 & 2003 & 2004 & 2005 & 2006 & 2007 & 2008 & 2009 & 2010 & 2011 & 2012 & 2013 \\
\hline U.S. & 4.57 & 4.98 & 5.23 & 5.14 & 5.01 & 4.8 & 4.7 & 4.6 & 4.5 & 4.5 & 4.5 & 4.52 & 4.3 \\
\hline CHINA & 0.86 & 0.96 & 1.03 & 1.05 & 0.92 & 1 & 1.1 & 1 & 1.1 & 1.3 & 1.2 & 1.26 & 1.4 \\
\hline JAPAN & 2.21 & 2.22 & 2.2 & 2.25 & 2.22 & 2.2 & 2.1 & 2.2 & 2.1 & 2.1 & 2.2 & 2.27 & 2.3 \\
\hline GERMANY & 3.6 & 3.7 & 3.82 & 3.86 & 3.73 & 3.6 & 3.6 & 3.5 & 3.7 & 3.7 & 3.6 & 3.62 & 3.6 \\
\hline FRANCE & 2.85 & 2.97 & 3.15 & 3.14 & 3.13 & 3.1 & 3 & 3 & 3.1 & 3.1 & 3.3 & 3.28 & 3.2 \\
\hline U.K. & 3.45 & 4.56 & 4.75 & 3.68 & 3.55 & 3.4 & 3 & 2.9 & 3 & 2.9 & 3.1 & 2.84 & 2.8 \\
\hline BRAZIL & 1.78 & 1.74 & 1.68 & 1.63 & 1.68 & 1.6 & 1.6 & 1.6 & 1.5 & 1.5 & 1.5 & 1.66 & 1.8 \\
\hline ITLAY & 2.46 & 2.58 & 2.63 & 2.74 & 2.73 & 2.5 & 3.2 & 2.4 & 2.4 & 2.3 & 2.3 & 2.27 & 2.2 \\
\hline RUSSIA & 1.51 & 1.81 & 2.13 & 2.21 & 2.15 & 2.3 & 2.4 & 2.3 & 2.5 & 2.3 & 2.3 & 1.24 & 1.2 \\
\hline INDIA & 0.56 & 0.67 & 0.62 & 0.65 & 0.61 & 0.6 & 0.6 & 0.6 & 0.6 & 0.7 & 0.7 & 0.78 & 0.8 \\
\hline WORLD & 3.15 & 3.38 & 3.48 & 3.43 & 3.18 & 3 & 3.1 & 2.9 & 3 & 2.9 & 2.8 & 2.81 & 2.8 \\
\hline
\end{tabular}

Source: SWISS RE, SIGMA NO.6/2002 TO NO.3/2014

The table explains the non-life insurance penetration in India as well as at the global level. Non-life insurance penetration is measured as a ratio of premium to Gross Domestic Product (GDP). It is clear from the table that non-life insurance penetration in India has shown a marginal increase during the period under study. It has increased from $0.56 \%$ in 2001 to $0.8 \%$ in 2013 . The world-wide non-life insurance penetration has increased initially up to 2004 but thereafter declined and reached to $2.8 \%$ in 2013. USA is at the top followed by Germany and France in non-life insurance penetration. In India, it is lowest as compare to the other countries of the world under study during the post reform period.

\subsection{Insurance Density and Penetration in India}

Year wise detail of insurance density and penetration in India has been given in Table 1.8 and graph 1.1 and 1.2.

Table 8. Insurance Density and Penetration in India

\begin{tabular}{lllllll}
\hline \multicolumn{2}{l}{ Year Density (US \$) Penetration } & & & & \\
\hline $\mathbf{2 0 0 1}$ & LIFE & NONLIFE & INDUSTRY & LIFE & NONLIFE & INDUSTRY \\
$\mathbf{2 0 0 2}$ & 9.1 & 2.4 & 11.5 & 2.15 & 0.56 & 2.71 \\
$\mathbf{2 0 0 3}$ & 11.7 & 3 & 14.7 & 2.59 & 0.67 & 3.26 \\
$\mathbf{2 0 0 4}$ & 12.9 & 3.5 & 16.4 & 2.26 & 0.62 & 2.88 \\
$\mathbf{2 0 0 5}$ & 15.7 & 4 & 19.7 & 2.53 & 0.64 & 3.17 \\
$\mathbf{2 0 0 6}$ & 18.3 & 4.4 & 22.7 & 2.53 & 0.61 & 3.14 \\
$\mathbf{2 0 0 7}$ & 33.2 & 5.2 & 38.4 & 4.1 & 0.6 & 4.8 \\
$\mathbf{2 0 0 8}$ & 40.4 & 6.2 & 46.6 & 4 & 0.6 & 4.7 \\
$\mathbf{2 0 0 9}$ & 41.2 & 6.2 & 47.4 & 4.6 & 0.6 & 4.6 \\
$\mathbf{2 0 1 0}$ & 57.7 & 6.7 & 54.3 & 4.6 & 0.6 & 5.2 \\
$\mathbf{2 0 1 1}$ & 49.7 & 8.7 & 64.4 & 4.4 & 0.7 & 5.1 \\
$\mathbf{2 0 1 2}$ & 42.7 & 10 & 59 & 3.4 & 0.7 & 4.1 \\
$\mathbf{2 0 1 3}$ & 41 & 11 & 53.7 & 3.17 & 0.78 & 3.95 \\
\hline
\end{tabular}

Source: SWISS RE, SIGMA NO.6/2002 TO NO.3/2014 


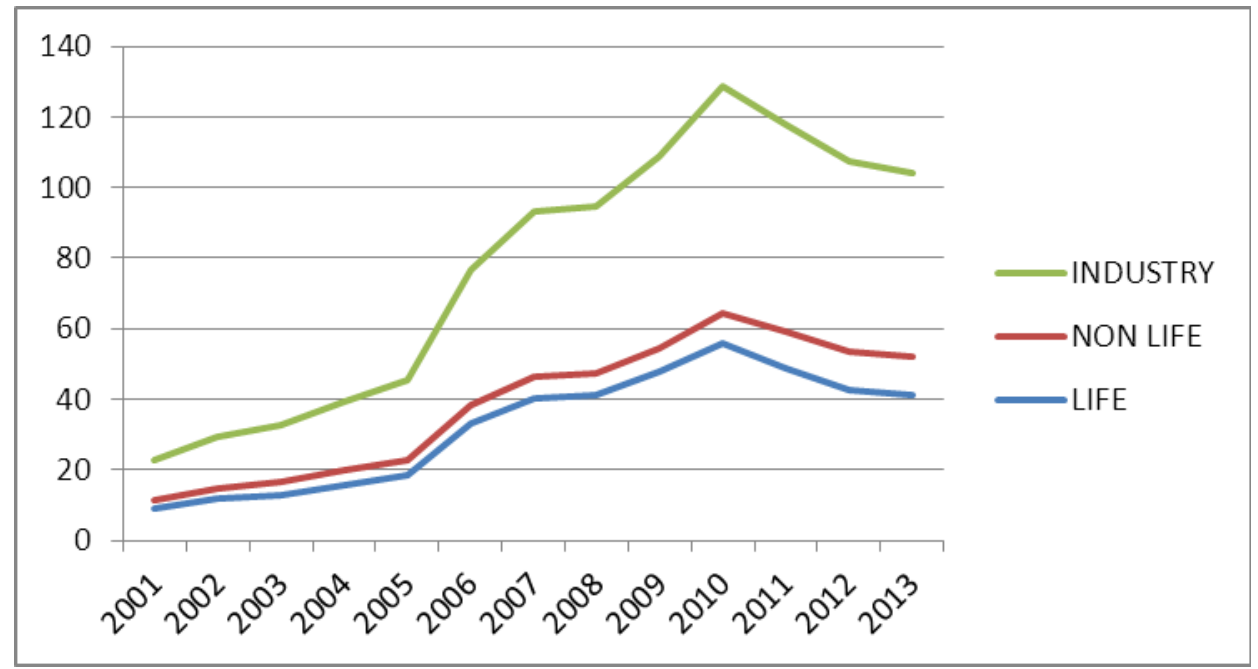

Graph 1. Insurance Density in India

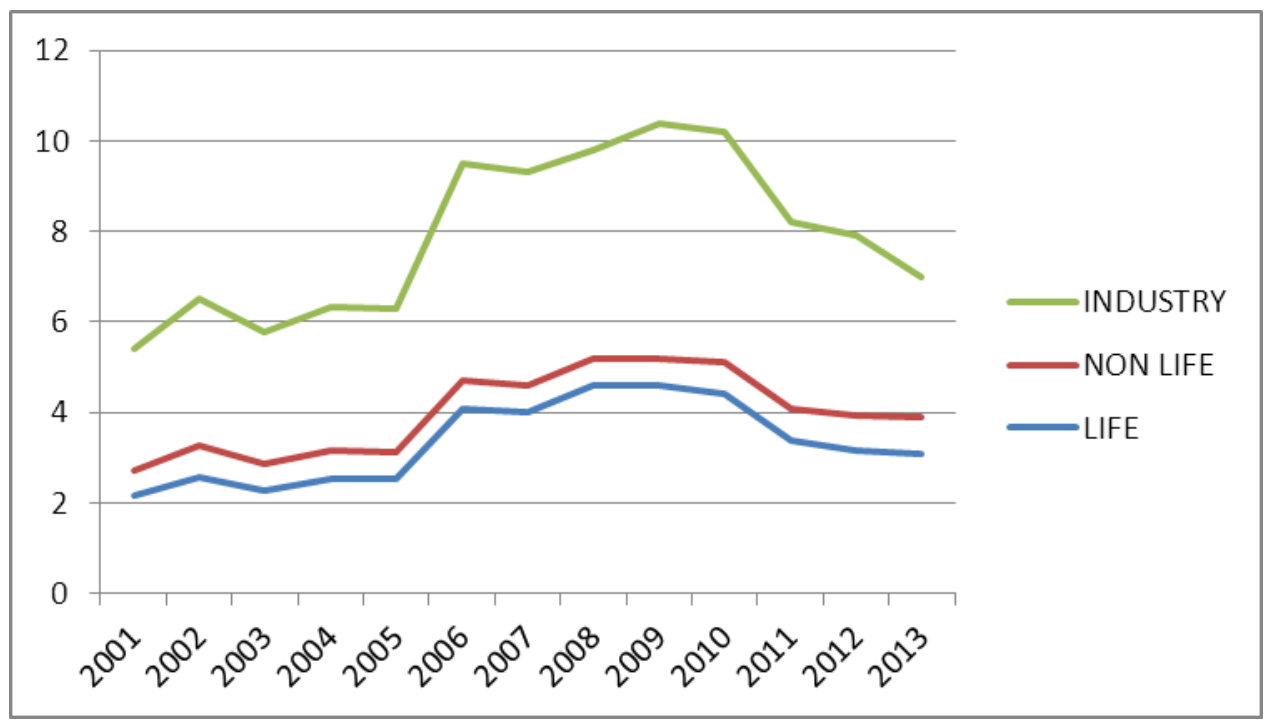

Graph 2. Insurance Penetration in India

It is evident from the table and from both the charts that since the opening of the insurance sector for private participation India has reported increase in both insurance density and penetration up to 2010. However, the increase has been almost entirely contributed by the life insurance sector. After 2011, it is showing a decline in the trend.

\section{Conclusion}

To study the growth of Indian Insurance Industry with reference to top economies of the world mainly three parameters i.e. insurance premium volume, insurance penetration and insurance density have been used. On the basis of the analysis of these parameters, we can conclude that Indian Insurance Industry has grown consistently during the period of study except last three years when it has shown some declining trend. No doubt, the rising trend of Indian Insurance Industry in all the parameters looks impressive, but if we compare the figures of Indian Insurance Industry with the figurers of other top economies of the word, we are at the lowest level in almost all the parameters under study. So we can further conclude that despite the growth of Indian Insurance Industries after its opening up for private players, a lot is still needed to do, to accelerate its growth to compete at global level. 


\section{References}

Banerjee T.K. (2004). Insurance Regulation in India and Future Directions. The Journal, Journal of Insurance Institute of India, $X X X, 13$

Festus M. Epetimehin. (2011). Achieving Competitive Advantage in Insurance Industry: The Impact of Marketing Innovation and Creativity. European Journal of Social Science, 19(1), 126.

Lai, G.C., \& Limpaphayom, P. (2003). Organizational Structure and Performance: Evidence from the Non-Life Insurance industry in Japan. The Journal of Risk and Insurance, 70(4), 735-757. http://dx.doi.org/10.1046/j.0022-4367.2003.00073.x

Rudolf, E. (2001). Profitability of the Non-Life Insurance Industry: Its Back to Basics Time. SWISS RE, SIGMA, 5, $1-38$.

Verma, S. (2000). Performance Appraisal of the General Insurance Corporation on India M. Phil. Thesis Submitted to Department of Commerce, Delhi School of Economics, University of Delhi, Delhi.

Annual reports of IRDA from 2001-02 to 2013-14

Annual reports of National Insurance Company Ltd. from 2001-02 to 2013-14

Annual report of New India Assurance Company Ltd. from 2001-02 to 2013-14

Annual report of United India Insurance Company Ltd. from 2001-02 to 2013-14

Annual report of United India Insurance Company Ltd. from 2001-02 to 2013-14

www.irda.gov.in

www.nationalinsuranceindia.com

www.newindia.com

www.orientalinsurance.org.in

www.uiic.co.in 